\title{
Lithostratigraphy \& microfacies analysis of Avanah Formation (Middle Eocene) in Gomaspan section northeast Erbil City, Kurdistan region, Iraq
}

\author{
Irfan Sh. Asaad \\ Dept. of Earth Sciences and Petroleum, College of Science, \\ Salahaddin University-Erbil, Erbil Kurdistan Region, Iraq. \\ Corresponding author:irfan.asaad@su.edu.krd
}

\begin{abstract}
Lithostratigraphy and microfacies analysis of the Avanah Formation (Middle Eocene) were studied in the Gomaspan section in the Bina Bawi anticline, northeast of Erbil city, Kurdistan Region, Iraq. The field observations refer that the formation attains $56 \mathrm{~m}$ of medium to thick-bedded yellow limestone, grey dolomitic limestone, and blue marly dolomitic limestone interbedded with thin beds of blue marl and dark grey shale with an interval of sandy limestone in the middle part and thin to medium bedded limestone interbedded with red mudstone. The petrographic study of 29 thin sections of Avanah carbonates revealed that most of the matrix is carbonate mud (micrite) with few microspar. The skeletal grains include benthic foraminifera, dasycladacean green algae, ostracods, calcispheres, pelecypods, rare planktonic foraminifera, and bryozoa, in addition to bioclasts. Non-skeletal grains encompass peloids, oncoids, intraclasts, and extraclasts with common monocrystalline quartz. Three different lithostratigraphic units were identified based on field observation and petrographic analysis. They are in ascending order: A-Thick bedded dolomitic marly limestone interbedded with shale. B- Bedded dolomitic limestone interbedded with shale and marl. C- Thin to medium bedded limestone interbedded with red mudstone. Depending on detailed microfacies analysis of carbonate rocks, three main microfacies and 12 submicrofacies are recognized. From the sum of all petrographic, facies, and textural analyses, it is concluded that Avanah Formation in the Gomaspan section was deposited in the shallow marine environment, semi-restricted lagoon, in lower and upper parts, and open lagoon environment in the middle part interval.
\end{abstract}

Keywords: Avanah; Iraq; lithostratigraphy; microfacies analysis; middle eocene.

\section{Introduction}

Mc Ginty first described the Avanah Formation in 1953 (Bellen et al., 1959) from well Kirkuk 116 on the Avanah dome of the Kirkuk anticline in the low folded Zone. In its type section, the Avana Formation comprises $210 \mathrm{~m}$ of dolomitized and recrystallized limestones of shoal facies with occasional beds of lagoonal dolomitized limestone. Its thicknesses in subsurface sections in northern Iraq are as follows: Kirkuk-117 (159 m), Butmah-I (503 m), Alan-1 (154 m), Atshan-1 $(138 \mathrm{~m})$, and Mushorah-1 $(550 \mathrm{~m})$. Laterally the Avanah Formation interfingers with Jaddala Formations in wells Sufaya-A2 and Najmah-30 (Jassim \& Buday, 2006). The Avanah Formation belonging to the late Lower Eocene- Upper Eocene cycle (Buday, 1980) and distributed in a belt 
along the boundary of the Foothill and High Folded Zones, and is thick in the area of the Foothill Zone of northern Iraq as an isolated carbonate shoal associated with a palaeoridge along the northeastern shoreline of the basin during a highstand of sea level (Jassim \& Buday, 2006). On the other hand, the Avanah Formation is characterized by the dominance of macro and microfossils and high porosity and permeability ratio, making its lower and middle parts a good hydrocarbon reservoir (Al-Hamdany \& Sulaiman, 2014).

Since the first description of the formation in Bellen et al. (1959), several studies have dealt with the Avanah Formation in terms of sedimentology, stratigraphy, and paleontology; these are the studies of Al-Omeri \& Sadek (1975), Sharbazheri \& Abawi. (1987), Al-Banna \& Al-Mutwali (2005), Barzani (2016) and Abdullah et al. (2020). The present study aims to clarify lithostratigraphy and comprehension of the depositional environment of the Avanah Formation in the Gomaspan section by using integrations of field, petrographic observations, and microfacies analysis.

\section{Location}

The studied area is located in the northeast of Erbil city in the Kurdistan Region of northern Iraq (Figure 1). The studied section, which was not covered by any previous works, is located about $300 \mathrm{~m}$ northeast of Gomaspan village and about $30 \mathrm{~km}$ northeast of Erbil city on the main road of Erbil-Dolly Smaquli area, in the southwestern limb of Bna Bawi Anticline (36 $16^{\prime} 48^{\prime \prime} \mathrm{N}$ and $44^{\circ}$ 20' 07" E) (Figure 2).

\section{Geologic Setting}

Avanah Formation is exposed in different areas of the High Folded Zone as a belt close to the boundary with the Low Folded Zone (Figure 1). The High Folded Zone is characterized by numerous folds and faults with major trending northwest-southeast (Al-Qayim et al., 2020). The Avanah Formation is located in the middle part of the tectonostratigraphic AP 10 mega sequence of Sharland et al. (2001). This mega sequence was split into two subsequences: The Paleocene Early Eocene sequence and the Middle to Late Eocene sequence (Jassim \& Buday, 2006). The Avanah Formation belongs to the Middle-Late Eocene subsequences, which is deposited in the SW of the emergent uplift along with the final phase of the subduction and closing of the remnant part of the Neo-Tethys Ocean. The other carbonate units of this subsequences are Dammam platform, Ratga fore slope, Jaddala deep basin and Pila Spi lagoonal formations (Al-Hashimi \& Amer, 1985). 


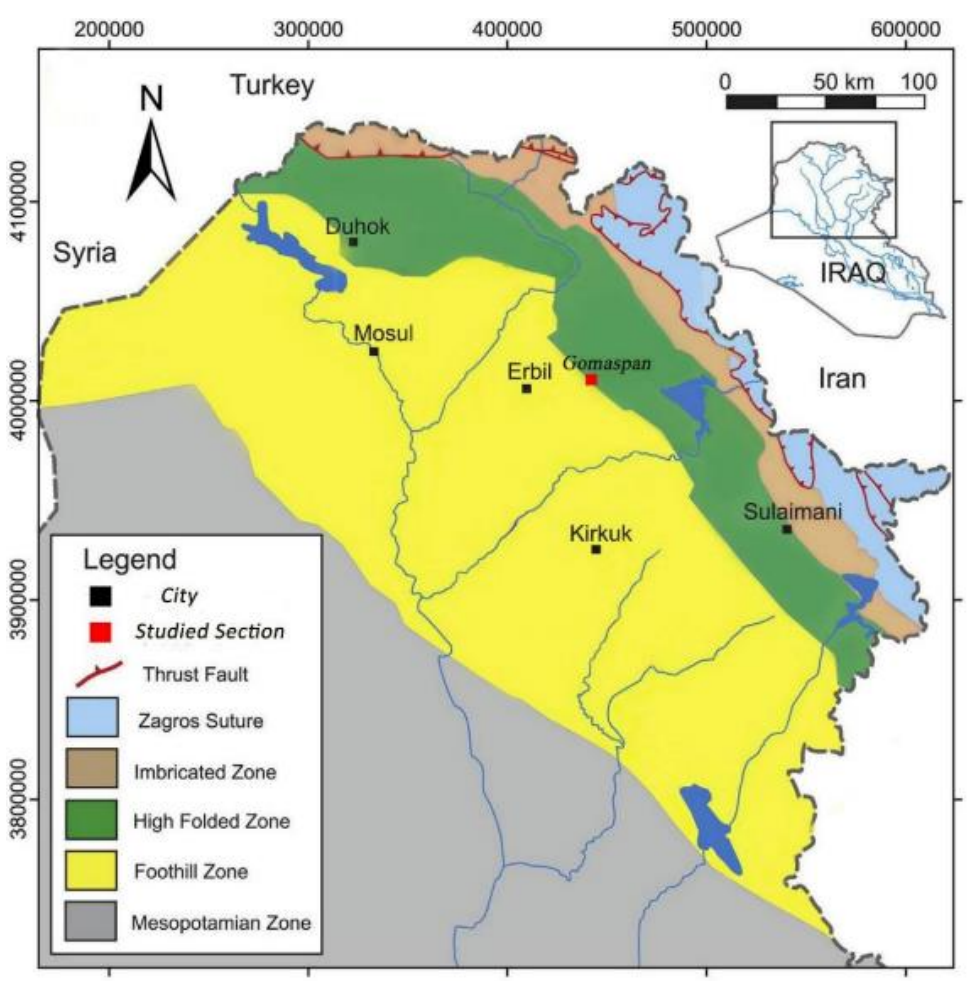

Fig. 1. Location and tectonic map of the studied area (after Jassim \& Goff, 2006).

Generally, the Avanah Formation in the eastern Erbil, from Koya in the east to Shaqlawa in the northeast, occurs as a tongue within the Gercus Formation and characterizing by lateral variation thickness (AL-Sakry, 1999). The Avanah Formation in the Gomaspan section crops out at the southwestern limb of the Bina Bawi anticline, which is characterized by NW-SE trending and verges to the SW (Awdal et al., 2013), which is linked to the NW with Pirmam anticline and latter proposed by Omer (2005) as NW continuation of Bina Bawi anticline which together may form one gigantic anticline that is over $75 \mathrm{~km}$ long (Figure 2). The stratigraphic successions around the studied area include Bekhme, Shiranish, and Tanjero formations from the Upper Cretaceous age; the latter is overlain by Tertiary units involving Kolosh, Khurmala, Gercus, Avanah, Pilaspi, Fatha (Lower Fars), Injana (Upper Fars), and further away Mukdadiya (Lower Bakhtiari) and Bai Hassan (Upper Bakhtiari) formations. The Avanah Formation in the studied section exists as a tongue within the red mudstone of the Gercus Formation (Figure 3a).

\section{Materials and methods}

To select a suitable section for the present study, comprehensive fieldwork was done between High Folded and Low Folded Zones, which involved the study of general geology and structural relationships of the Tertiary succession in the surrounding area. The Gomaspan area was chosen for the present study since it is characterized by well-exposed fresh beds due to cutting their surface by shovel vehicle machines and removing the sedimentary covers because it will be a part of the 
proposed earth dam in that area. The outcrop was described and measured in detail, logging the lithology and mineralogy. The primary lithologies of the studied outcrop are limestone, dolomitic limestone, marly limestone, sandy limestone, marl, and shale.

A total of 29 fresh samples were collected from the carbonate beds. The samples were collected at every change in lithology or color (random sampling). All samples were taken along a line perpendicular to the bedding plane. The upper and lower parts of each sample were also marked and detailed description of samples (Macroscopic study) using a hand lens and dilute $\mathrm{HCl}$ acid was performed. The sum of 29 thin sections was prepared at Salahaddin University -Erbil. At least one thin section for each sample was prepared. The thin sections were oriented and stained with the Alizarin Red Solution (ARS) following the procedure of Friedman (1959) for the identification of calcite and dolomite.

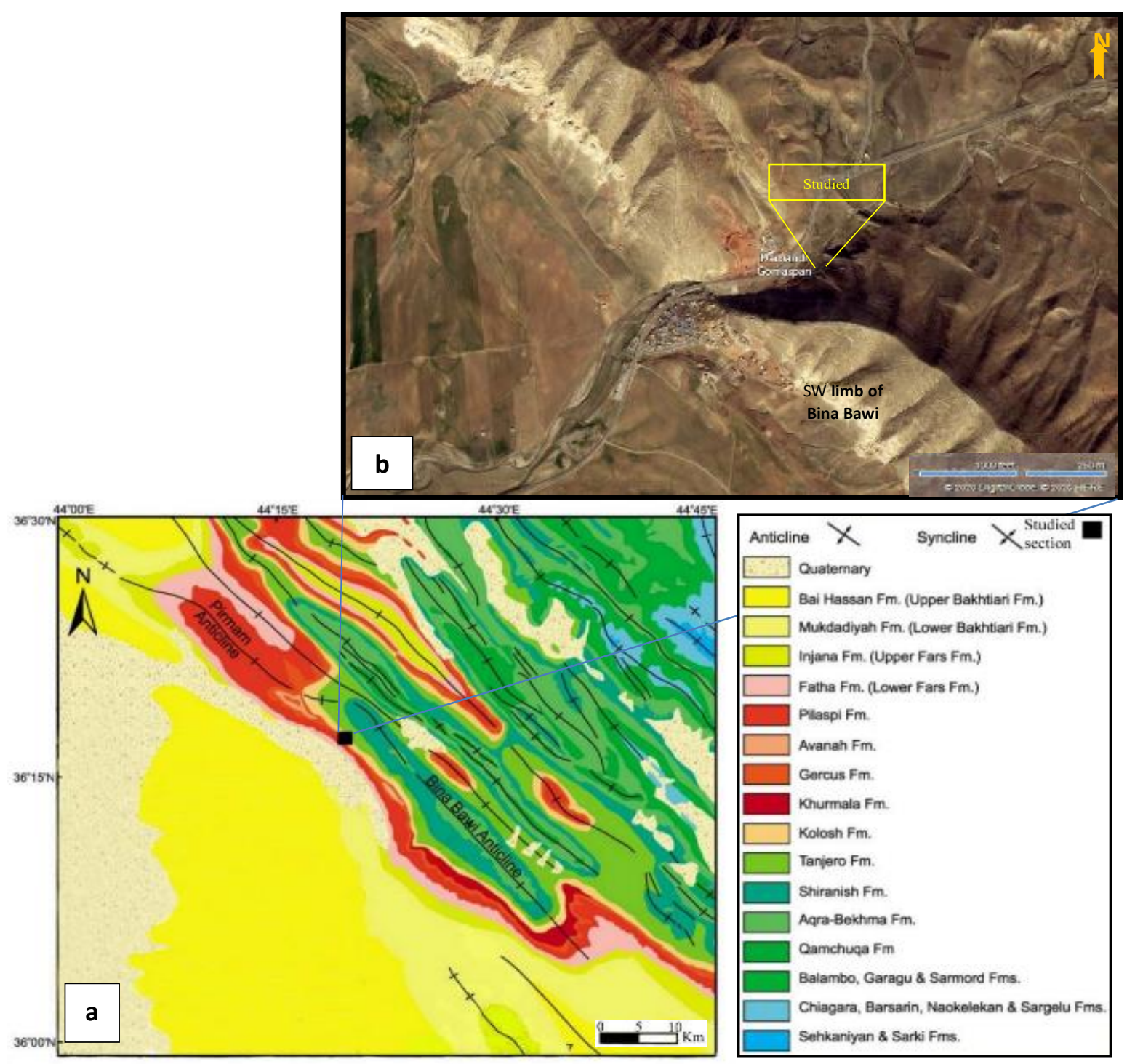

Fig. 2. (a) Geological and structural map of Bina Bawi and Pirmam anticlines showing studied section (after Awdal et al., 2013). (b) Satellite image of Gomaspan section (from Bing Map). 


\section{Lithostratigraphy}

The total thickness of the Avanah Formation in the Gomaspan section is about 56 meters. Based on field inspection and petrographic analysis, the Avanah Formation in the studied area can be divided into three units, which are in ascending order (Figure 3a):

\subsection{Thick bedded marly dolomitic limestone interbedded with shale (Unit A)}

This unit occupies the base of the Avanah Formation in the studied section and is underlain by thin beds of red mudstone of the Gercus Formation (Figure 3b). It comprises $9.5 \mathrm{~m}$ of thick (50-100 $\mathrm{cm}$ ) bedded of grey marly dolomitic limestone interbedded with laminated (less than $1 \mathrm{~cm}$ wide) brown to grey shale (Figures $3 b \& c$ ). The sedimentary structure of this unit is thin horizontal (planar) millimeter-thick laminations. The carbonate beds of this unit are characterized by calcite (Figure 3d) and sulphur geodes (Figure 3e), bearing macrofossils (pelecypods) (Figure 4a), and bituminous (Figure 4b). The macrostyliolitic porosity observed on the carbonate beds of the unit (Figure $3 \mathrm{~d}$ ) is formed by chemical compaction diagenesis when the created stylolites contribute to making some pores around their sutures due to the passing of $\mathrm{CO} 2$ - rich solution along with them (Carrozi and Bergen, 1987). Sedimentary structures of this unit are thin horizontal (planar) millimeter-thick laminations and burrowing (Figure 4a).

\subsection{Bedded marly dolomitic limestone interbedded with shale and marl (Unit B)}

The total thickness is about $30 \mathrm{~m}$. The lower $3.8 \mathrm{~m}$ is composed of medium $(30-50 \mathrm{~cm})$ bedded of grey marly limestone and fossiliferous dolomitic limestone interbedded with thin beds of grey shale and blue marl (Figure $4 \mathrm{c}$ ), followed by $30 \mathrm{~cm}$ of intraformational conglomerate (Figures $4 \mathrm{~d}$ $\&$ e). The middle $2.3 \mathrm{~m}$ comprises thick (50-100) bedded dolomitic limestone interbedded with thin beds of grey shale. Subsequently, $1 \mathrm{~m}$ consists of yellowish-grey of medium to thick-bedded sandy limestone (Figure 4f). The upper $22.5 \mathrm{~m}$ comprise of alternation of thin to medium (10-50 $\mathrm{cm})$ and medium to thick $(50-100 \mathrm{~cm})$ bedded of fractured grey marly dolomitic limestone interbedded with narrow beds of grey shale and blue marl (Figure 5a). 

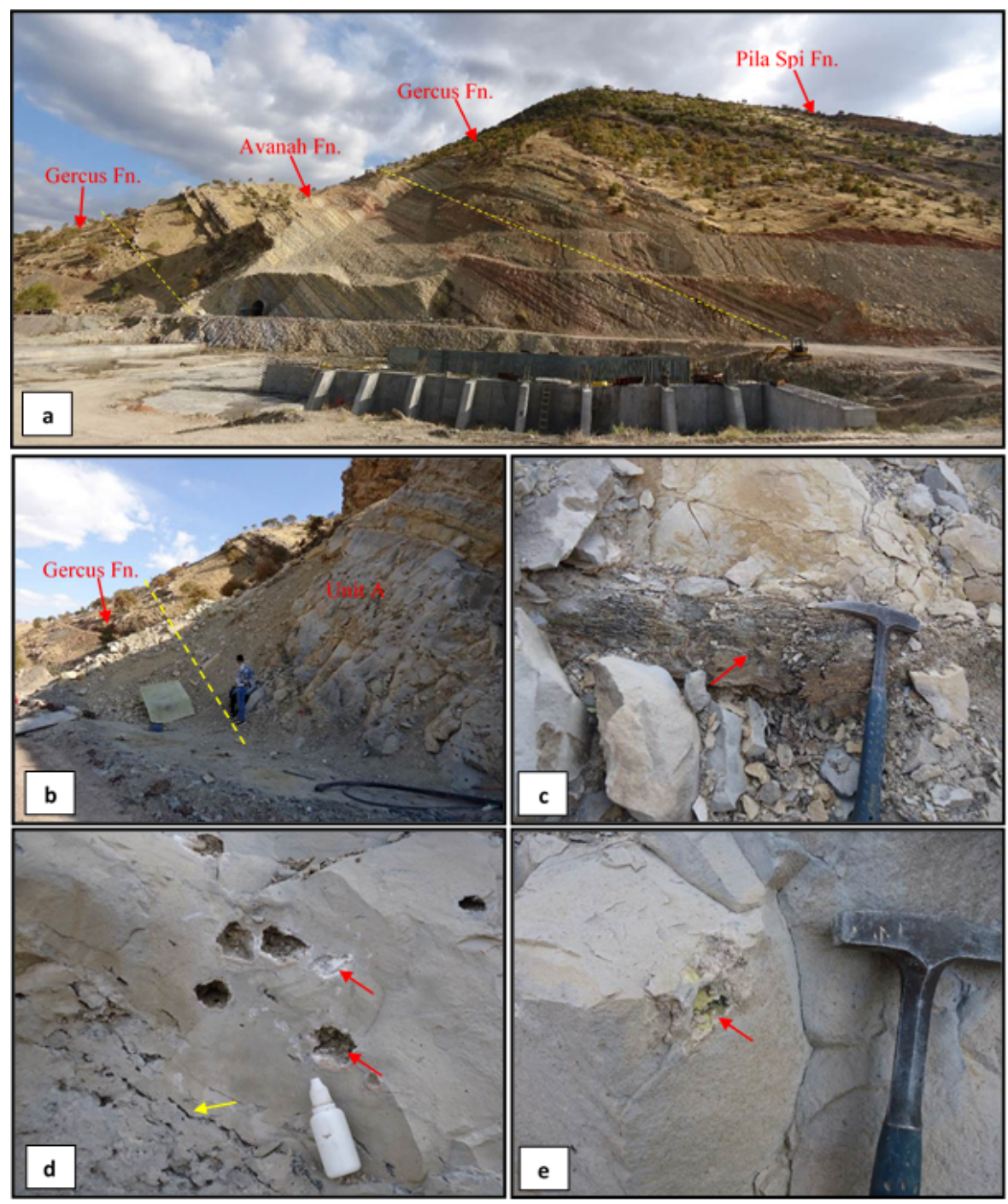

Fig. 3. Field photographs showing: (a) Avanah Formation inter tongue within red mudstones of Gercus Formation which overlain by Late Eocene Pila Spi Formation in Gomaspan section. (b) Thick bedded dolomitic marly limestone interbedded with shale (unit A) overlain red mudstone beds of Gercus Formation. (c) Laminated brown to grey shale (red arrow) interbedded within thick yellow to grey dolomitic limestone. (d) Calcite geodes (red arrows) in the fractured dolomitic limestone affected by chemical compaction formed Macrostylolitic porosity (yellow arrow). (e) Sulphur geodes (red arrow) characterized by yellow color and had rotten eggs smell on the thick dolomitic limestone of Unit A.

Generally, deferent sedimentary structures were observed in this unit, including horizontal planner lamination, bending (Figure 4f), symmetrical ripple marks (Figures 5a \& b), and slump structure which is post depositional structure supposed to be formed by tectonic activity related to the final phase of the subduction and closing of the remnant part of the Neo-Tethys Ocean (Figure 5d). Calcite geodes and veins (Figure 4f), besides pyrite nodules, also occurred on the carbonate beds of this unit (Figure 5e). 
5.3 Thin to medium bedded limestone interbedded with red mudstone (Unit C)

This unit overlain unit B and is regarded as a transition zone between Carbonates of Avanah Formation and clastics of Gercus Formation. It comprises $16.5 \mathrm{~m}$ of thin to medium bedded (10$50 \mathrm{~cm}$ ) yellow to white marly limestone interbedded with calcareous red mudstone and yellow marl (Figure 5f). The sedimentary structures of this unit are thin horizontal (planar) millimeterthick laminations.

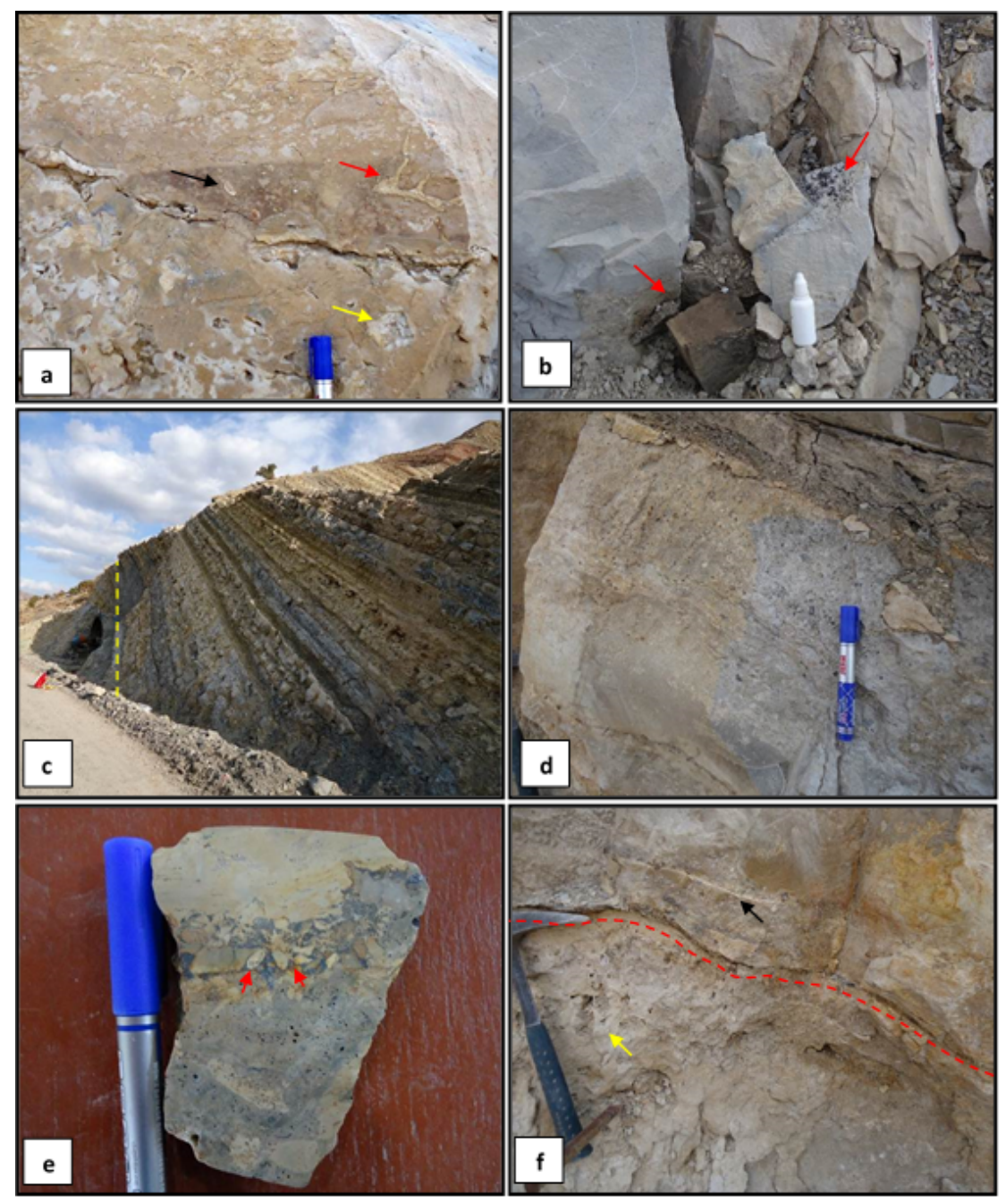

Fig. 4. Field photographs showing: (a) Burrowing (red arrow), bivalves (black arrow) and calcite concretion (yellow arrow) filled the molluscan mold on the dolomitic limestone beds of Avanah Formation, calcite concretion (yellow arrow). (b) Bituminous limestone bed (red arrow). (c) Bedded dolomitic limestone interbedded with shale and marl overlain unit A. (d) Intraformational conglomerate $(30 \mathrm{~cm})$ overlain dolomitic limestone and underlain grey shale. (e) Slabs of conglomerate bed show intraclasts (red arrows). (f) Bending in (red dash-line) in the Sandy limestone beds of Avanah Formation affected by bioturbation (yellow arrow) and has calcite veins (black arrow). 

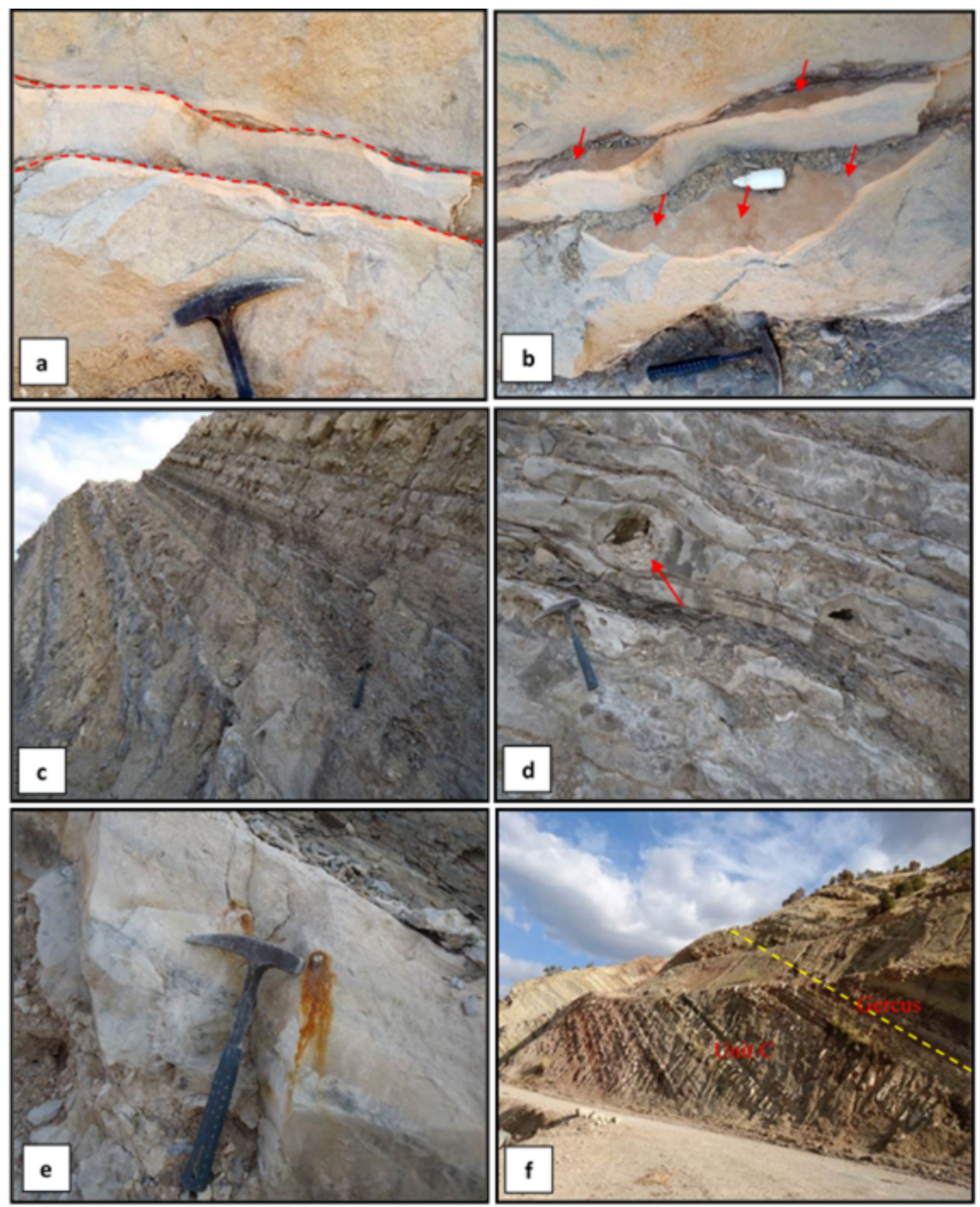

Fig.5. Field photographs showing: (a) Symmetrical ripple marks formed in sandy limestone beds (red dash line). (b) Surface of ripple marks in the sandy limestone beds (red arrows). (c)Thin to medium bedded grey dolomitic marly limestone interbedded with grey shale and blue marl in the upper part of unit B. (d) Slump sedimentary structure formed on the medium to thick dolomitic limestone beds of Avanah Formation (red arrow). (e) Pyrite nodules in the fractured dolomitic limestone beds. (f)Thin to medium bedded limestone interbedded with red mudstone and yellow marl overlain by red mudstone of Gercus Formation. 


\section{Microfacies types}

According to the classification of Dunham (1962), three main microfacies types were identified in the carbonate rocks of the Avanah Formation in the studied section. Each was subdivided into several submicrofacies on the remarkable fossil type and diagenetic processes. Table (1) manifests the main and submicrofacies recognized in the petrographic study of the formation.

Table 1. Microfacies types of the Avanah Formation in the Gomaspan section

\begin{tabular}{|c|c|c|c|c|}
\hline $\begin{array}{l}\text { Main } \\
\text { microfacies } \\
\text { Dunham (1962) }\end{array}$ & $\begin{array}{l}\text { Subdivision of Dunham } \\
\text { (1962) }\end{array}$ & $\begin{array}{l}\text { Diagnostic features (main } \\
\text { skeletal grain + common } \\
\text { diagenetic process) }\end{array}$ & $\begin{array}{l}\text { SMF } \\
\text { Flügel } \\
(\mathbf{1 9 8 2})\end{array}$ & $\begin{array}{l}\text { Environment of } \\
\text { deposition }\end{array}$ \\
\hline \multirow{3}{*}{ Lime Mudstone } & Dolomitized lime mudstone & -Dolomitization+ Pyritization & 23 & $\begin{array}{l}\text { Restricted platform } \\
\text { (lagoon) }\end{array}$ \\
\hline & $\begin{array}{l}\text { Benthic foraminiferal lime } \\
\text { mudstone }\end{array}$ & $\begin{array}{l}\text { - Textularia plummerae } \\
\text { - Neomorphism+ Dolomitization }\end{array}$ & 9 & $\begin{array}{l}\text { Shallow lagoon with } \\
\text { open circulation }\end{array}$ \\
\hline & $\begin{array}{l}\text { Dasycladacean lime } \\
\text { mudstone }\end{array}$ & $\begin{array}{l}\text {-Dasycladacean green algae } \\
\text {-Silicification+ Ferruginous } \\
\text { material + Organic matter. }\end{array}$ & 8 & $\begin{array}{l}\text { Shelf lagoons } \\
\text { with circulation }\end{array}$ \\
\hline \multirow{5}{*}{ Lime Wackestone } & $\begin{array}{l}\text { Sandy-miliolid lime } \\
\text { wackestone }\end{array}$ & $\begin{array}{l}\text {-Miliolid+ Monocrystalline quartz } \\
\text {-Dissolution+ } \\
\text { Micritization }\end{array}$ & 8 & $\begin{array}{l}\text { Shelf lagoon with } \\
\text { circulation }\end{array}$ \\
\hline & Alveolina lime wackestone & $\begin{array}{l}\text {-Alveolina } \\
\text {-Micritization+ Dolomitization }\end{array}$ & 9 & $\begin{array}{l}\text { Shallow lagoon } \\
\text { with open circulation }\end{array}$ \\
\hline & $\begin{array}{l}\text { Planktonic foraminifera - } \\
\text { intraclasts lime wackestone }\end{array}$ & $\begin{array}{l}\text {-Globigerina }+ \text { intraclasts } \\
\text {-Dolomitization+ Micritization }\end{array}$ & 9 & $\begin{array}{l}\text { Shallow lagoon with } \\
\text { open circulation }\end{array}$ \\
\hline & $\begin{array}{l}\text { Sandy-Peloidal lime } \\
\text { wackestone }\end{array}$ & $\begin{array}{l}\text {-Monocrystalline quartz+ peloids } \\
\text {-Dolomitization+ Dissolution }\end{array}$ & 8 & $\begin{array}{l}\text { Shelf lagoons } \\
\text { with circulation }\end{array}$ \\
\hline & $\begin{array}{l}\text { Sandy-benthic foraminifera } \\
\text { lime wackestone }\end{array}$ & $\begin{array}{l}\text {-Valvulina } \\
\text {-Dissolution }+ \text { Micritization }\end{array}$ & 18 & $\begin{array}{l}\text { Shelf lagoons } \\
\text { with open circulation }\end{array}$ \\
\hline \multirow{4}{*}{ Lime Packstone } & $\begin{array}{l}\text { Ostracoda- calcispheres } \\
\text { lime packstone }\end{array}$ & $\begin{array}{l}\text {-Ostracods }+ \text { Calcispheres } \\
\text {-Neomorphism+ Dissolution }\end{array}$ & 9 & $\begin{array}{l}\text { Shallow lagoon with } \\
\text { open circulation }\end{array}$ \\
\hline & $\begin{array}{l}\text { Bryozoan-ostracoda- } \\
\text { intraclasts lime packstone }\end{array}$ & $\begin{array}{l}\text {-Bryozoa +Ostracods } \\
\text {-Neomorphism+ Dolomitization }\end{array}$ & 9 & $\begin{array}{l}\text { Shallow lagoon with } \\
\text { open circulation }\end{array}$ \\
\hline & $\begin{array}{l}\text { Benthic foraminifera- } \\
\text { bioclast-dasycladacean lime } \\
\text { packstone }\end{array}$ & $\begin{array}{l}\text { Rotaliid }+ \text { Spirloculina }+ \\
\text { Dasycladacean green algae }+ \\
\text { Bioclasts } \\
\text {-Dolomitization }+ \text { Cementation }\end{array}$ & 18 & $\begin{array}{l}\text { shelf lagoons } \\
\text { with open circulation }\end{array}$ \\
\hline & Oncoid lime wackestone & $\begin{array}{l}\text {-Oncoids } \\
\text {-Cementation+ Pyritization }\end{array}$ & 22 & Subtidal (lagoon) \\
\hline
\end{tabular}




\subsection{Lime mudstone microfacies}

Mudstone microfacies are widespread in the studied section but less common than the lime wackestone microfacies. It is characterized by the dominance of micrite with rare (generally less than 10\%) grains content (Dunham, 1962). The identified skeletal grains in this microfacies are benthic foraminifera (Valvulina sp. and Textularia plummerae.) (Figure 6b) with dasycladacean green algae (Figure 7c). It is observed within the unit (A) in the lower part of the formation and unit (C) in the upper part of the studied section. The characteristic diagenetic process in these facies is dolomitization (Figure 6a). Other diagenetic types involve pyritization, micritization, and silicification.

\subsection{Lime wackestone microfacies}

This microfacies is considered the most common among other microfacies of Avanah carbonate. It is commonly found in different parts of the Gomaspan section, particularly in the middle part (Unit B). It is defined by involving grains ranging between 10 to $50 \%$ in the micritic matrix (Dunham, 1962). Skeletal grains include benthic foraminifera (Miliolids (Quinqueloculina sp.) (Figure 6d), Alveolina sp. (Figure 6e), and Textularia sp.) and planktonic foraminifera (Globigerina sp.) (Figure 6f). While non-skeletal grains involve peloids (Figure 7a) and extraclasts, mainly monocrystalline quartz (Figures $6 \mathrm{~d} \& 7 \mathrm{~b}$ ). It is subjected to diagenetic processes such as dolomitization, pyritization, dissolution, silicification, micritization, and neomorphism.

\subsection{Lime packstone microfacies}

Packstone microfacies are less common than other microfacies and are observed in the lower and middle parts of the studied section of the Avanah Formation. In this microfacies, skeletal grains increase up to $60 \%$ in the packstone, leaving minor micrite between grains-supported limestones (Dunham, 1962). The petrographic investigation of these microfacies lead to recognize the Ostracoda- calcispheres lime packstone submicrofacies (Figure7c), bryozoan - Ostracodaintraclasts lime packstone submicrofacies (Figure 7d), Rotaliid-bioclasts-dasycladacean lime packstone submicrofacies (Figure 7e) and Oncoid lime packstone submicrofacies (Figure 7f). The common diagenetic processes that affected it are neomorphism, cementation, and pyritization. 

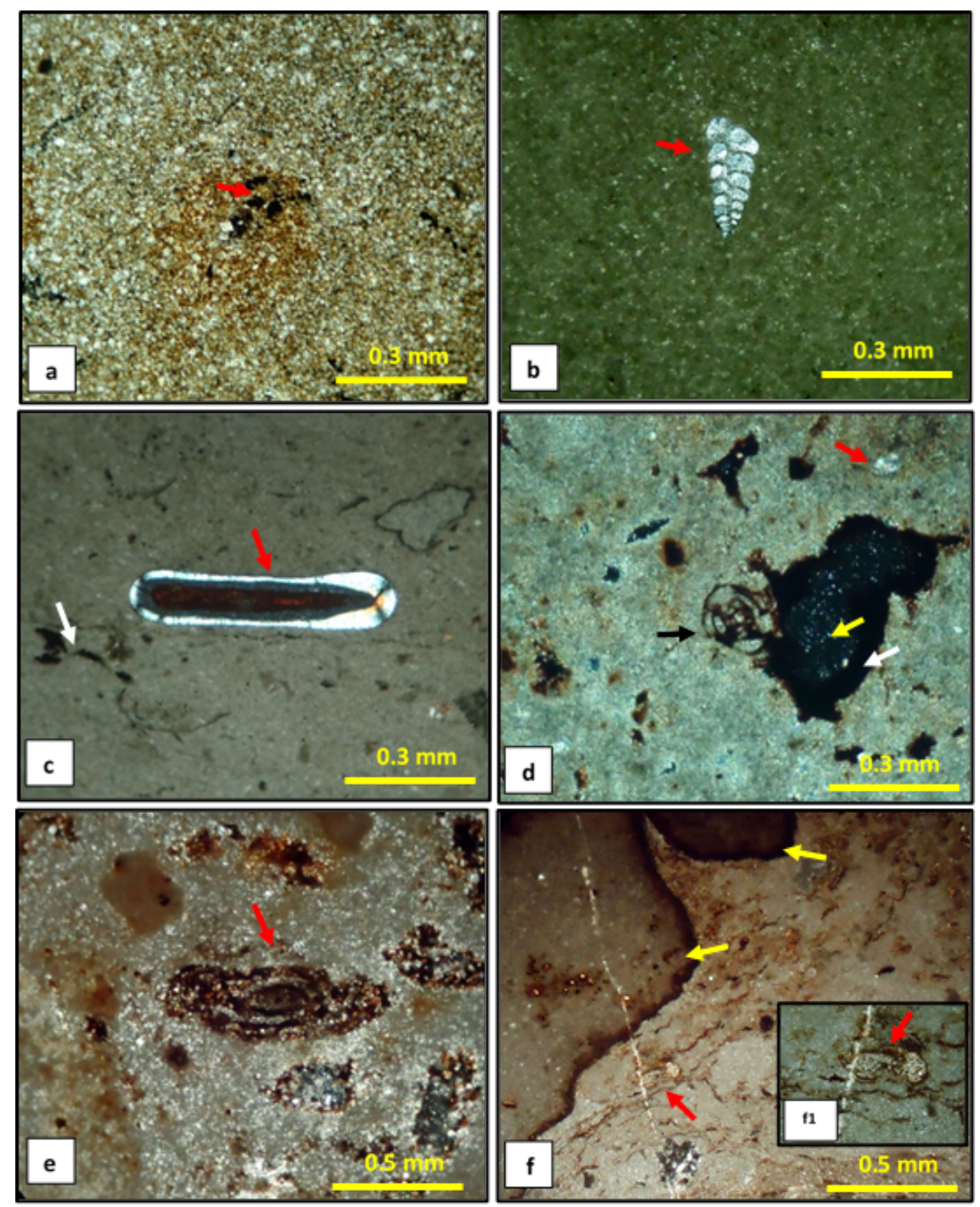

Fig. 6. Photomicrographs showing microfacies types of Avanah Formation in Gomaspan section: (a) Dolomitized lime mudstone submicrofacies subjected to pyritization (red arrow). GA1., P.P. (b) Benthic foraminifera (Textularia plummerae (red arrow)) lime mudstone submicrofacies. GA9., P.P. (c) Dasycladacean lime mudstone submicrofacies, dasycladacean shell filled by ferruginous material in the center and affected by silicification in the outer layers (red arrow), the groundmass affected by organic matter (white arrow). GA26., X.N. (d) Sandy (red arrow)miliolid (black arrow) wackestone submicrofacies, a mold of undefined shell subjected to affected by pyritization (white arrow) and dissolution (yellow arrow). GA2., X.N. (e) Alveolina (red arrow) lime wackestone submicrofacies. GA14., X.N. (f) Planktonic foraminifera (Globigerina) (red arrow)-intraclasts (yellow arrow) wackestone submicrofacies. GA11., P.P. (f1) enlarged photomicrographs of Globigerina sp. GA11., X.N.

Key= AG: Avanah-Gomaspan, P.P: Plane polarized light, X.N: Crossed Nicoles. 


\section{Facies associations}

Based on the integration of the recognized microfacies analysis and field observations of the Avanah Formation in the Gomaspan section, two basic types of facies associations were identified according to their environmental interpretation, which is as follows (Figure 8).

\subsection{Semi-restricted lagoon Facies Association (FA1)}

This association is equivalent to standard facies zone 7 and 8 of Wilson (1975) and Standard Microfacies 8, 22, and 23 of Flügel (1982). It is observed in the lower $9.5 \mathrm{~m}$ and upper $39 \mathrm{~m}$ of the Avanah Formation. The lower $9.5 \mathrm{~m}$, which occupies unit (A), consists of $9.3 \mathrm{~m}$ of thickbedded grey dolomitic marly limestone-rich lime mudstone to wackestone with rare packstone interbedded with laminated brown to grey shale. It shows thin horizontal (planar)millimeter-thick lamination, burrowing, brecciation and bioturbation. The pelecypod macrofossils with molds of mollusks are also observed. While the upper part of the association comprises $22.5 \mathrm{~m}$ of thin to medium and medium to thick-bedded fractured grey marly dolomitic limestone rich in lime mudstone to wackestone interbedded with narrow beds of grey shale and blue marl and $16.5 \mathrm{~m}$ of thin to medium bedded yellow to white marly limestone-rich lime mudstone to wackestone interbedded with calcareous red mudstone and yellow marl. Horizontal planner lamination, slump sedimentary structure, burrowing, and calcite geodes and veins, and pyrite nodules are seen on the carbonate beds of this association. Petrographically, the association, contains skeletal grains, including benthic foraminifera (Textularia plummerae, Quinqueloculina sp. and Valvulina sp.), Dasycladacean green algae and bioclasts. While non-skeletal grains involve peloids, oncoids, and extraclasts, mainly monocrystalline quartz grains. The groundmass is mainly lithified carbonate mud (micrite) which is occasionally transformed to microspar by neomorphism. Dolomitization is a characterized diagenetic process of this association, particularly in mudstone microfacies. Other significant diagenetic processes include pyritization, dissolution, cementation, silicification, and micritization. 

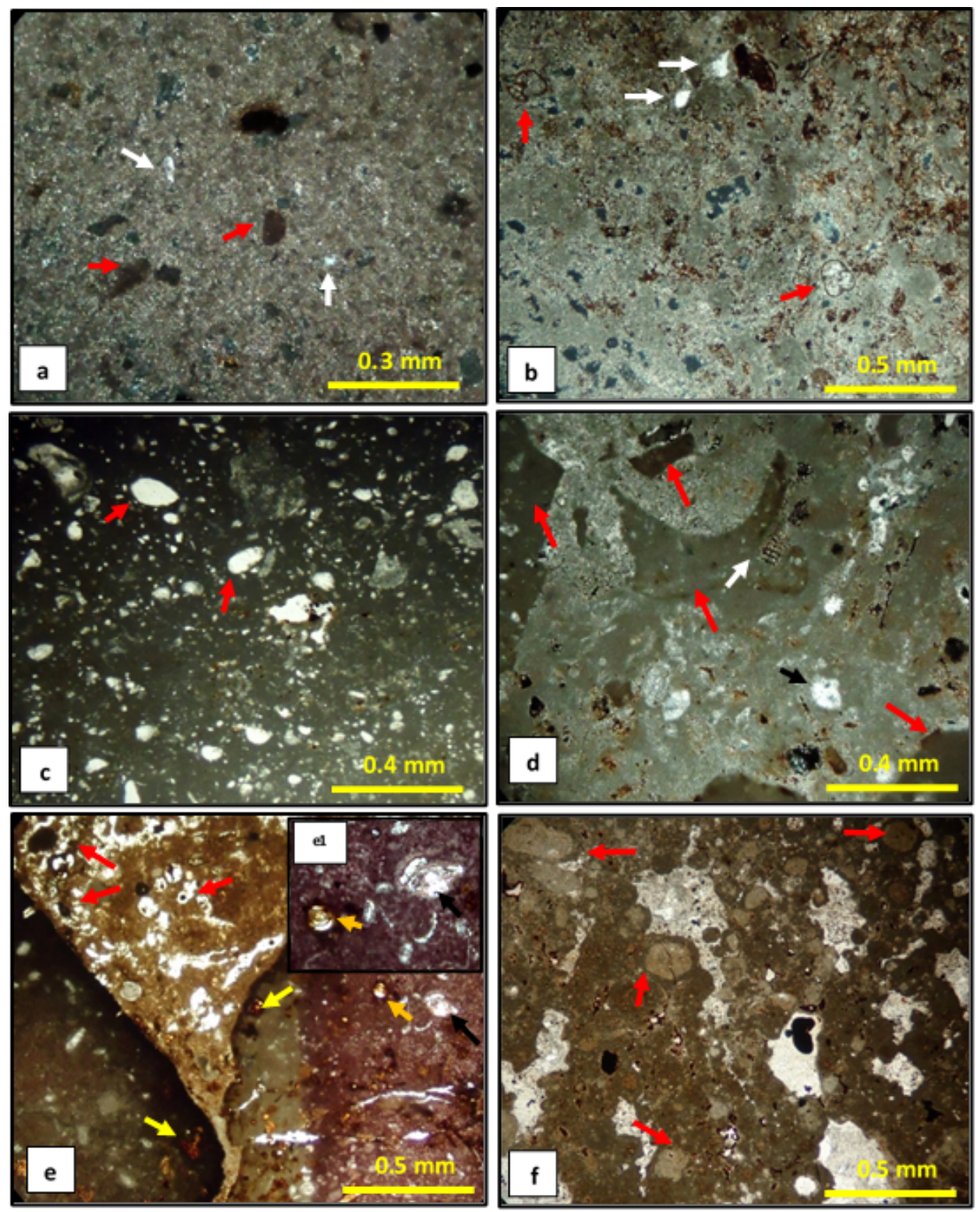

Fig. 7. Photomicrographs showing microfacies types of Avanah Formation in Gomaspan section: (a) Sandy (white arrows)-peloidal (red arrows) lime wackestone.GA9., X.N. (b) Sandy (white arrows)-benthic foraminifera (Valvulina (red arrows))- lime wackestone submicrofacies which is characterized by high porous and the foraminiferal test affected by micritization envelop. GA16., X.N. (c) Ostracoda (red arrows)- calcispheres lime packstone submicrofacies. GA10., P.P. (d)

Bryozoan (white arrow)-ostracoda (black arrow)-intraclasts (red arrows) lime packstone submicrofacies.GA15., P.P. (e) Benthic foraminifera (Rotaliid (black arrow), Spirloculina sp.

(orange arrow))-bioclasts (yellow arrows)-dasycladacean (red arrows) lime packstone submicrofacies formed in intraformational conglomerate grains .GA15., P.P. (e1) enlarged photomicrographs of part of (e) displaying Rotaliid (black arrow) and Spirloculina sp. (orange arrow). (f) Oncoid (red arrows) lime wackestone submicrofacies subjected to cementation and pyritization GA2., P.P.

Key= AG: Avanah-Gomaspan, P.P: Plane polarized light, X.N: Crossed Nicoles. 


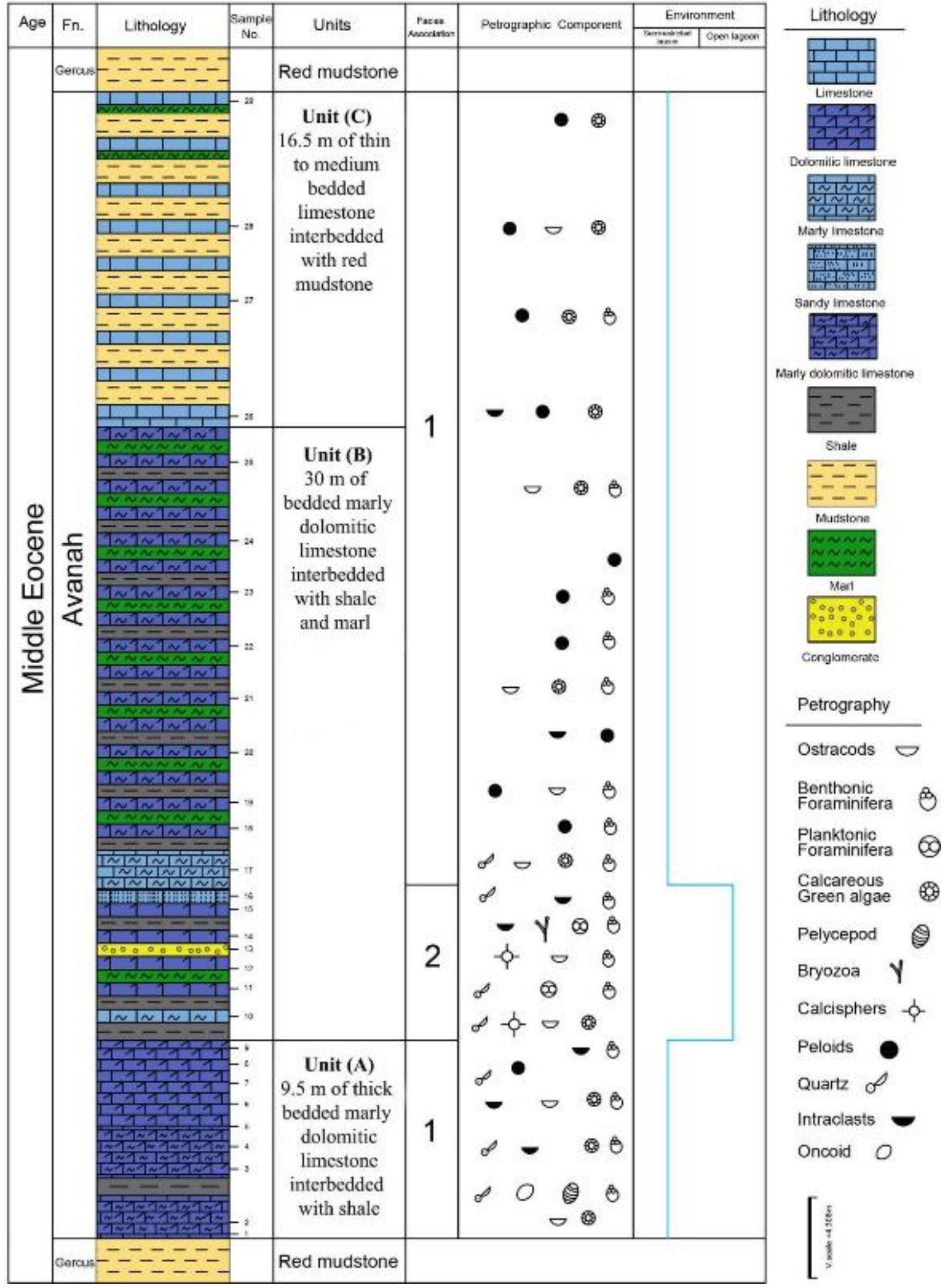

Fig. 8. Columnar sections and Facies Associations of the Avanah Formation in Gomaspan Section. 
Interpretation: This facies association is rich in dolomitized lime mudstone followed by lime mudstone and lime wackestone. The dominance of the micrite matrix microfacies within this association indicates that the sea bottom was stagnant and calms enough for lime mud to accumulate (Boggs, 2006). Dolomitized lime mudstone is expected in the restricted platforms (Wilson, 1975; Flügel, 1982). The porcelaneous imperforate miliolids (Quinqueloculina sp.) dominate in the restricted lagoon with hypersaline water (Murray, 2006). The presence of Textularia plummerae represents a shallow marine environment with semi-restricted conditions (Asaad and Balaky, 2018). The dominance of dasycladacean algae reflects a shallow water environment of less than $10 \mathrm{~m}$ deep (Aguirre et al., 2000). The occurrence of peloids within this association indicates shallow warm waters (Flügel, 2010). Oncoidal lime packstone, which occurred at the base of the studied section, indicates an Inner-platform environment (shallow subtidal lagoon) (Flügel, 2010; Pleş et al., 2019). Monocrystalline quartz is believed that it deposited in low energy, restricted intertidal, supratidal, and subtidal environments (Nowrouzi et al., 2015), and its association with benthic foraminifera in lime wackestone microfacies reflects restricted lagoon setting (Ameen et al., 2019). Pelecypods have a wide environmental range, from near-shore to off-shore environments (Clarkson, 1998), but existing as association with mentioned fossils supposed to be deposited in a lagoonal environment. The laminated dark grey shale is thought to be deposited in a shallow lagoon environment with very slow-moving water (Blatt \&Tracy, 1996). Calcite and sulphur geodes are diagenetic products that are supposed to be formed by minerals precipitation from aqueous solution filling the dissolved nodules in the rock, mainly composed of evaporates (Milliken, 2003). Burrowing is common in low-energy, shelf lagoons with a circulation environment (Flügel, 2010).

\subsection{Open Lagoon Facies Association (FA2)}

The association is equivalent to Faces Zone 7 of Wilson (1975) and Standard Microfacies 9 and 18 of Flügel (1982). It is equipped with the lower $7.5 \mathrm{~m}$ of unit (B). It consists of medium to thickbedded grey to blue marly limestone and fossiliferous dolomitic limestone rich in lime wackestone to packstone with rare mudstone interbedded with thin beds of grey shale and blue marl and medium to thick-bedded yellowish-grey sandy limestone rich in lime packstone with $30 \mathrm{~cm}$ interval of intraformational conglomerate in the middle part of the facies association. The obvious sedimentary structures of this facies are horizontal planner lamination and symmetrical ripple marks in addition to calcite geodes and veins.

The microscopic investigation of thin sections revealed that the skeletal grains of this association involves benthic foraminifera (Miliolids (Spirloculina sp.), Rotalia sp., Textularia sp. and Valvulina sp.), planktonic foraminifera (Globigerina sp.), ostracods, bryozoa, dasycladacean green algae, calcispheres, and bioclasts. Non-Skeletal grains consist of peloids, intraclasts, and extraclasts. The main groundmass is micrite which tentatively changed to microspar. The main diagenetic processes upon the beds of these facies are cementation, micritization, pyritization, dissolution, and neomorphism. 
Interpretation: The appearance of planktonic foraminifera (Globigerinid) with benthic fauna indicates a lagoonal environment connecting with open marine (Open shelf) (Ahmad et al., 2020). The occurrence of calcispheres in a shallow water environment with planktonic foraminifera represents deposition toward the deep basin (Al-Haj, 2020). Bryozoa is found in a shallow lagoon with open circulation (Flügel, 2010). The dominance of ostracod fragments reflects an openmarine lagoon across the platform (Flügel, 2010). Intraclasts can create in many environments but most typically are formed in regimes with intermittently high energy conditions (Scholle and Scholle, 2003); therefore, are supposed to be developed in an open lagoon setting with high energy conditions in Avanah Formation. Intraformational lime conglomerates are commonly deposited below the storm wave base in the inner shelf environment (Scholle et al., 1983). They are supposed to be created from the reworking of subtidal sediments by storms (Dravis, 1979) in occasional subsiding in the open lagoon basin. Sandy-benthic foraminifera lime wackestone is common in the mixed energy part of the lagoon (Soleimani et al., 2014) in the shallow lagoon with open circulation (Flügel, 2010). The symmetrical ripple marks on sandy limestone beds of the Avanah Formation are thought to be formed in shallow water in the in and out motion of bidirectional waves of sandy size particles bottom in inner shelf environments (Wilson \& Jordan, 1983). Highly bioturbated carbonates are inferred to be shallow-marine environments with a low sedimentation rate (Strasser et al., 1999).

Thus, from above observations and interpretations of both facies' associations indicated that the Avanah Formation was deposited in a semi-restricted lagoonal environment with an interval of the open lagoonal setting in the middle part.

A schematic block diagram was drawn to imply all these interpretations and the updated vision of the Avanah environment in the Gomaspan section (Figure 9). This figure illustrates the inferred paleoenvironmental conditions and elements of the Avanah Formation in the Gomaspan section in the Kurdistan region-Northern Iraq.

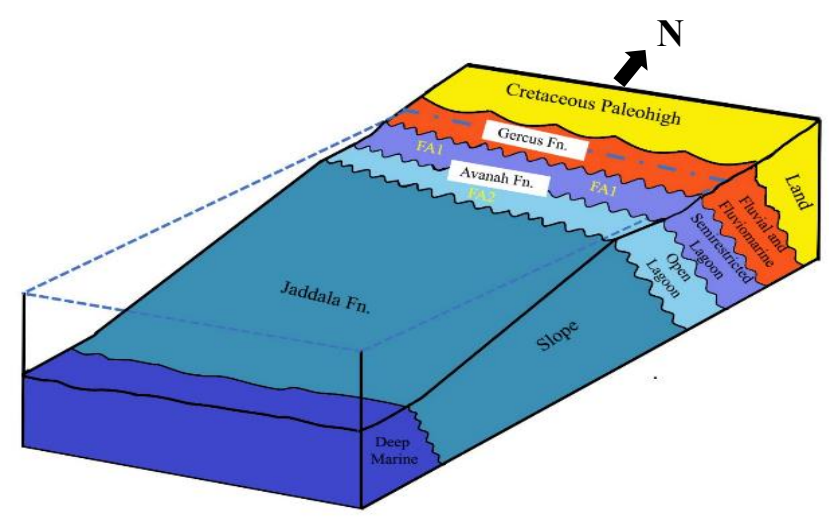

Fig. 9. Schematic Model of Avanah Depositional Environment (Middle Eocene) in Gomaspan section. (FA1: Semi-restricted lagoon Facies Association, FA2: Open Lagoon Facies Association). 


\section{Conclusions}

8.1 The Avanah Formation in the Gomaspan section consists of 56 m medium to thick-bedded yellow limestone, grey dolomitic limestone, dolomitic marly limestone interbedded with thin beds of marl and dark grey shale with an interval of sandy limestone in the middle part and thin to medium bedded limestone interbedded with red mudstone. It is inter-tongue within Gercus Formation.

8.2 Based on field observation and petrographic analysis, three different lithostratigraphic units were identified in the Avanah Formation in the studied section. They are in ascending orders:

a. Thick bedded dolomitic marly limestone interbedded with shale.

b. Bedded dolomitic limestone interbedded with shale and marl.

c. Thin to medium bedded limestone interbedded with red mudstone.

8.3 The petrographic components of Avanah carbonate are as follows:

a. Matrix composed mainly of micrite with little recrystallized microspar.

b. Non-skeletal grains involve peloids, oncoids, intraclasts, and extraclasts, commonly monocrystalline quartz.

c. Skeletal grains include benthic foraminifera, dasycladacean green algae, ostracods, calcispheres, pelecypods, rare planktonic foraminifera, and bryozoa, in addition to bioclasts.

8.4 Depending on detailed microfacies analysis of limestone following Dunham (1962), three main microfacies and twelve submicrofacies are recognized in the studied thin sections of Avanah Formation in the studied area. These facies were subdivided according to their environmental interpretation, vertical and lateral transitions into two basic types of facies associations: semirestricted and open lagoonal environment

8.5 The study of petrography, facies, and textural analyses, concluded that Avanah Formation in the Gomaspan section was deposited in the shallow marine environment, semi-restricted lagoon, in the lower and upper part, and open lagoon environment in the intervals in the middle part.

\section{ACKNOWLEDGMENTS}

I would like to express my sincere gratitude to the Earth Sciences and Petroleum Department at Salahaddin University-Erbil for using their workshop in thin section preparation. Miss Kanar Mohammed and Mr. Aram S Ahmed, fresh graduate geologists from Salahaddin University Erbil, also appreciated their help during fieldwork and computer facilities. 


\section{References}

Abdullah, M.A., Hassan, F.N. \& Saleh, M.A. (2020) Microfacies and Palaeoenvironment of Avanah Formation (Middle Eocene) GeliBessri in Dohuk City / North of Iraq. Tikrit Journal of Pure Science, 25 (1): 85-93

Aguirre, J., Riding, R. \& Braga, J.C. (2000) Late Cretaceous incident light reduction: evidence frombenthic algae. Lethaia, 33: p213 - 213

Ahmad, S., Wadood, B., Khan, S., Ullah A., Mustafa, G., Hanif, M. \& Ullah, H. (2020) The sedimentological and stratigraphical analysis of the Paleocene to Early Eocene Dungan Formation, Kirthar Fold and Thrust Belt, Pakistan: implications for reservoir potential. Journal of Sedimentary Environments, 5: 473-492

Al-Banna, N.Y. \& Al-Mutwali, M.M. (2005) Microfacies Evidences for Eocene Sequence Stratigraphy of Jaddala/Avanah Formations, Sinjar Area, Northwest Iraq. Rafidain journal of science, 16(2E): 1-12

Al-Haj, M.A. (2020) Sedimentological Study of the Hartha Formation in Selected Oilfields, Northern Iraq. IRANIAN JOURNAL OF SCIENCE AND TECHNOLOGY TRANSACTION ASCIENCE, 44(2): 389-400

AL-Hamdany, A.M.\& Sulaiman MA (2014) Porosity of Avanah Formation and its Stratigraphical Distribution in Selected Wells of Kirkuk Oil Field. Iraqi National Journal of Earth Sciences, 14(1): 49-66

Al-Hashimi, H. A. \& Amer R. M. (1985) Tertiary microfacies of Iraq. Directorate General for Geological Survey \& Mineral Investigation. Baghdad. Pp.159.

Al-Omeri, F.S. \& Sadek A. (1975) Stratigraphy of Alveolina bearing strata from Duhok area Northern Iraq, Neues Jahrbuch fur Geologie und Palaontologie-Monatshefte , 10:577- 585

Al-Qayim, B. A., Kharajiany, S. O. \& Wise, Sh. W (2020) Biostratigraphic analysis of the K/Pg boundary using calcareous Nannofossil from Sulaimani area, Kurdistan Region, Iraq. Kuwait Journal of Science, 47(4):92-105

Al- Sakry, S.I. (1999) Stratigraphy and Facies of Paleogene Carbonate formations of the Selected Sections, Northeastern Iraq. M.Sc. thesis, Baghdad University, Iraq 
Ameen, F. A., Fattah, A. I., Qader, B. O. (2020) Microfacies and depositional environment of the Upper Oligocene and Lower Miocene successions from Iraqi Kurdistan Region. Kuwait Journal of Science, 47(4):127-136

Asaad, I. S., \& Balaky, S. M. (2018) Microfacies Analysis and Depositional Environment of Khurmala Formation (Paleocene-Lower Eocene), in the Zenta Village, Aqra District, Kurdistan Region, Iraq. Iraqi Bulletin of Geology and Mining, 14(2): 1-15

Awdal, A.H., Braathen, A., Wennberg, O.P., Sherwani, G.H. (2013) The characteristics of fracture networks in the Shiranish formation of the Bina Bawi Anticline; comparison with the Taq Taq field, zagros, Kurdistan, NE Iraq. Petroleum Geoscience, 19(2): 139-155

Barzani B.A. (2016) Microfacies, depositional environment and sequence stratigraphy of Avanah Formation from selected sections in Iraqi Kurdistan Region. Msc. thesis, Salahaddin UniversityErbil, Iraq.

Bellen, R.C., Van Dunnington, H.V., Wetzel, R. \& Morton, D., (1959) Lexique Stratigraphique International: Asie, Iraq, 3c (10a): 333

Blatt, H. \& Tracy, R.J. (1996) Petrology: igneous, sedimentary, and metamorphic (2nd ed). W.H. Freeman, New York. USA.

Boggs, S.J. (2006) Principles of Sedimentology and Stratigraphy. 3rd ed. Prentic- Hall. Pp. 662. Buday, T. (1980) The Regional Geology of Iraq, Stratigraphy and Paleogeography, Dar Al-Kutub Publication, University of Mosul, Iraq (1). Pp.445.

Carozzi, A.V. \& Bergen, D.V. (1987) Stylolitic porosity in carbonates: A critical factor for deep hydrocarbon production. Journal of Petroleum Geology, 10(3):267-282

Clarkson, E.N.K. (1998) Invertebrate Palaeontology and Evolution. London, England, Allen 38 and Unwin). Pp. 468

Dunham, R.H. (1962) Classification of carbonate rocks according to depositional texture. In: Ham, W.E., edition. Classification of carbonate rocks. American Association of Petroleum Geologists (1): 108-121

Dravis, J. (1979) Rapid and widespread generation of Recent oolitic hardgrounds on a highenergy Bahamian Platform, Eleuthera Bank, Bahamas. Journal of Sedimentary Research, 49(1):195-207

Flügel, E. (1982) Microfacies Analysis of Limestones, Springer - Verlag, Berlin. Pp. 633. 
Flügel, E. (2010) Microfacies of Carbonate Rocks, Analysis, Interpretation and Application.Springer-Verlag, Berlin. Pp.976

Friedman, G.M. (1959) Identification of carbonate minerals by staining methods, Journal of 8 Sedimentary and Petrography, 29 (2): 87-97

Jassim, S.Z. \& Buday, T. (2006) Middle Paleocene- Eocene Megasequenc AP10, chapter 13, In: Jassim SZ, Goff JC (2006) Geology of Iraq. Dolin, Prague and Moravian Museum, Brno, Czech Republic. Pp. 155-168

Jassim, S.Z. \& Goff, J.C. (2006) Geology of Iraq. Dolin, Prague and Moravian Museum, Brno. Pp.341.

Milliken, K.L. (2003) Geodes, In: Middleton,G.V., Church, M.V., Coniglio, M., Hardie, L.A. \& Longstaffe, F. J. (eds.), Encyclopedia of Sediments \& Sedimentary Rocks. Springer.

Murray, J. W. (2006) Ecology and applications of benthic foraminifera. Cambridge university press, UK. Pp.426.

Nowrouzi, Z., Mahboubi, A., Moussayi-Harami, R.\& Ghaemi, F. (2015) Facies Analysis and Sequence Stratigraphy of Silurian Carbonate Ramps in the Turan (Kopeh-Dagh) and Central Iran Plates, Acta Geologica Sinica (English Edition): 7-23.

Omer, A.A. (2005) An integrated structural and tectonic study of the BinaBawi-Safin-Bradost Region in Iraqi Kurdistan. Ph.D thesis, Salahaddin University, Erbil

Pleş, G., Oprişa, A., Bucur, I., Săsăran, E., Mircescu, C., Oltean, G. \& Iacob R (2019) The central-western Getic Carbonate Platform: Upper Jurassic to Lower Cretaceous biostratigraphy and sedimentary evolution of the Cioclovina-Băniţa sector (Southern Carpathians, Romania). Facies, 65(3): 32.

Scholle, P.A., Bebout, D.G. \& Moore, C.H. (1983) Carbonate depositional environments.

Bulletin - American Association of Petroleum Geologists Memoir, 33: 172-210.

Scholle, P.A. \& Scholle, D.S. (2003) Petrography of Carbonate Rocks: Grains, Textures, Porosity, Diagenesis. AAPG, Memoir 77, USA. Pp.459.

Sharbazheri, K.M. \& Abawi, T.S. (1987) Larger Foraminifera from the Avanah Formation (Middle Eocene) of Dhouk area, Northern Iraq. Journal of Geologic Society, 20: 70-88. 
Sharland,P.R. , Archer, R., Casey, D.M., Davies, R.B., Hall, S.H., Heward, A.P., Horbury, A.D. \& Simmons, M.D. (2001) Arabian Plate Sequence Stratigraphy, Geo Arabia, Special publication 2. Gulf Petro Link. Bahrain. Pp.372.

Soleimani, B., Monjezi, K. \& Malaki, S. (2014) Microfacies, Diagenetic and Depositional Environment of Kazhdumi Formation (Aptian-Albian), Dezful Embayment, Zagros. NW Iran. Journals of Geology and Geoscience, 3(154): 2.

Strasser, A., Pittet, B., Hillgartner, H. \& Pasquier, R.J. (1999) Depositional sequences in shallow carbonate-dominated sedimentary systems: concepts for a high-resolution analysis. Sedimentary Geology, 128: 201- 221.

Wilson, J.L. (1975) Carbonate Facies in Geologic History. Springer-Verlag, Berlin. Pp.471.

Wilson, J.L. \& Jordan, C. (1983) Middle shelf, in Scholle, P. A., D. G. Bebout, and C. H. Moore (eds.), Carbonate depositional environments: American Association of Petroleum Geologists Mem,33: 297-344

Submitted: $\quad 25 / 11 / 2020$

Revised: $\quad 11 / 07 / 2021$

Accepted: $\quad 10 / 08 / 2021$

DOI: $\quad 10.48129 /$ kjs.11183 